\title{
Biology, diversity and strategies for the monitoring and control of triatomines - Chagas disease vectors
}

\author{
Jane Costa ${ }^{1 /+}$, Marcelo Lorenzo ${ }^{2}$ \\ 'Laboratório de Biodiversidade Entomológica, Instituto Oswaldo Cruz-Fiocruz, Rio de Janeiro, RJ, Brasil 2Laboratório de Triatomíneos e \\ Epidemiologia da Doença de Chagas, Instituto de Pesquisas René Rachou-Fiocruz, Belo Horizonte, MG, Brasil
}

Despite the relevant achievements in the control of the main Chagas disease vectors Triatoma infestans and Rhodnius prolixus, several factors still promote the risk of infection. The disease is a real threat to the poor rural regions of several countries in Latin America. The current situation in Brazil requires renewed attention due to its high diversity of triatomine species and to the rapid and drastic environmental changes that are occurring. Using the biology, behaviour and diversity of triatomines as a basis for new strategies for monitoring and controlling the vectorial transmission are discussed here. The importance of ongoing long-term monitoring activities for house infestations by $\mathrm{T}$. infestans, Triatoma brasiliensis, Panstrongylus megistus, Triatoma rubrovaria and R. prolixus is also stressed, as well as understanding the invasion by sylvatic species. Moreover, the insecticide resistance is analysed. Strong efforts to sustain and improve surveillance procedures are crucial, especially when the vectorial transmission is considered interrupted in many endemic areas.

Key words: Triatominae - behaviour - sylvatic species - colonization - control strategies - Chagas disease

The study of the biology, diversity and distribution of triatomines began after the discovery of the American trypanosomiases by Carlos Chagas, in 1909 (Neiva 1910, Neiva \& Lent 1941, Lent \& Wygodzinsky 1979, Galvão et al. 1998, 2003). The precise mapping of their occurrence, domestic infestations and the natural infection rates for the different triatomine species is critical for understanding the challenges and threats posed by vectorial transmission (Silveira \& Vinhaes 1999, Silveira 2000, Costa et al. 2002, 2003, López-Cardenas et al. 2005). Understanding their host searching behaviour and activity patterns (Guerenstein \& Lazzari 2009) as well as their choice of environments (Guarneri et al. $2002,2003)$ is also necessary. In addition to the previously mentioned characteristics, dispersion and reproductive strategies are essential for creating models to predict re-infestation processes (Gurevitz et al. 2006). Altogether, these aspects represent most of the variables needed for the development of pro-active control actions against domiciliary infestation.

Currently, there are 140 species of triatomines described and recognised as valid taxa (Lent \& Wygodzinsky 1979, Galvão et al. 2003, Forero et al. 2004, Garcia et al. 2005, Costa et al. 2006, Galvão \& Angulo 2006, Bérenger \& Blanchet 2007, Costa \& Félix 2007, Martinez et al. 2007, Sandoval et al. 2007, Patterson et al. 2009, Schofield \& Galvão 2009). Of this total, 61 species are

Financial support: $\mathrm{CNPq}$

+ Corresponding author: jcosta@ioc.fiocruz.br

Received 17 May 2009

Accepted 10 June 2009 present in Brazil (Galvão et al. 2003), where the most diverse triatomine fauna is found. This is due to the continental dimension of Brazil, comprising distinct biomes that include some of the richest biodiversity on our planet: the Amazon, the Atlantic Forest, the Pantanal and the Cerrado (IBAMA 2009). To better illustrate triatomine diversity, it is important to mention that in the North-Eastern Region of Brazil, 21 species have been collected that are either infesting or invading domiciles, even though most of those species were considered strictly sylvatic (Costa et al. 2003). A specific example can be found in the state of Pernambuco, which is relatively small, encompassing only $98,938 \mathrm{Km}^{2}$ (IBGE 2008), but comprises five differentiated mesoregions: Sao Francisco, Araripe, Agreste, Zona da Mata and the Metropolitan Region. In this state, 12 species have been captured in domiciliary ecotopes and, recently, 13 distinct phenotypes of Triatoma brasi-liensis Neiva, 1911 were reported in a variety of natural and artificial ecotopes. This geographical variation could also influence triatomine diversity. Nevertheless, the correlation between the distinct phenotypes of $T$. brasiliensis and their vectorial capacity still needs to be investigated (Neiva-Lima et al. 2008, Costa et al. 2009).

For both the states of Minas Gerais and Bahia (BA), 14 triatomine species have been captured in domiciliary units, representing a significant diversity in terms of triatomine fauna (Costa et al. 2003). In the almost unexplored Amazon Region, 18 triatomine species have been recorded (Coura et al. 2002). This region corresponds to more than $40 \%$ of the Brazilian territory and possesses one of the highest biodiversities on the planet. According to government sites, more than $700,000 \mathrm{~km} 2$ of the Amazon Forest has been devastated, representing $6.5 \%$ of the total area (IBGE 2008). The lack of data on probable new habitats for triatomines that are losing their original habitat due to environmental pressures, the 
possible existence of new species and the lack of detailed studies for some of the already recorded species impair the estimation and precision of predictions for the spread of Chagas disease in the Amazon Region. A biogeographical revision of the triatomine species based on ecological patterns shows different degrees of synanthropism interpreted as a behavioural gradient starting with the mere invasion of a single house by an adventitious adult and eventually leading to the stable infestation of human dwellings by large breeding vector colonies (Abad-Franch \& Monteiro 2007). Recently, the entomological investigation of the first autochthonous case of Chagas disease in the western Brazilian Amazon was reassessed and specimens of Rhodnius pictipes Stål 1872 and Rhodnius robustus Larrousse, 1927 infected with trypanosomatids were collected in the intradomicile and in the sylvatic ecotopes. These findings emphasise the increasing risk of Trypanosoma cruzi infection transmission in the Amazon Region (Fé et al. 2009). Nevertheless, studies suggest that the degradation of sylvatic environments promotes the dislodgment of insects into new ecotopes, fundamentally affecting humans and their associated domestic animals (Forattini et al. 1978, Romaña et al. 2003). Unconventional vectorial transmission related to professional activity was also observed in the municipalities of Santa Isabel do Rio Negro and Barcelos, which are located in the microregion of the Negro River in the state of Amazonas. Rhodnius brethesi Matta, 1919, a sylvatic species known as piaçavas' lice that is present in the native palm tree Leopoldinia piassaba Wallace, 1853, has been incriminated as the responsible vector for the transmission of Chagas disease to those who as collectors of piaçaba fibres. This species has been documented to voraciously feed on humans (Mata 1919, Coura et al. 1994).

Distinct from the majority of the Amazon Region, other vast areas of Brazil were colonised at least 200 years ago. Today, field data have shown that the following sylvatic species are frequently found in domiciliary and peridomiciliary areas: Triatoma vitticeps (Stål, 1859), Triatoma rubrovaria (Blanchard, 1843) and Panstrongylus lutzi (Neiva \& Pinto, 1923) (Gonçalves et al. 1998, Almeida et al. 2000, Freitas et al. 2004, Souza et al. 2008), among others. More recently, Triatoma sherlocki Papa, Jurberg, Carcavallo, Cerqueira \& Barata 2002 was captured in Gentio do Ouro, in the north central part of BA, colonising human dwellings (Almeida et al. 2009, unpublished observations). The area in which these colonies were found is not covered by the Control Programme of Chagas Disease. In addition, it is important to mention the increasing infestation rates by $T$. brasiliensis (Costa et al. 2003, Sarquis et al. 2004) in semi-arid areas of the Brazilian Northeast and by Triatoma sordida Stal, 1859 in wide Cerrado areas (Diotaiuti et al. 1995, Pelli et al. 2007). Therefore, the positive results achieved with the control measures intended against Triatoma infestans (Klug, 1834) should not be interpreted as an endpoint in the struggle against vectorial transmission. The diverse findings reporting sylvatic populations of relevant vectors, together with increasing reports about sylvatic species invading and colonising domiciles, make it evident that new challenges have the possibility of occurring.
Previous studies carried out by Mazza (1943) in Argentina, Torrico (1946) in Bolívia and Barreto et al. (1963) in Brazil have called attention to the fact that T. infestans could be found in different sylvatic ecotopes. Recently, in this ever-changing epidemiologic scenario, new tools exploiting the behaviour and the genetics of T. infestans revealed that wild foci of this species may be much more widespread than previously thought. Moreover, the high genetic diversity observed in a microregion suggests that the Andean Region is the starting point for the dispersion throughout several South American countries (Noireau et al. 2000, 2002, 2005, Panzera et al. 2004). The increasing migration movements and current environmental changes (Briceno-Leon \& Galvan 2007) could also favour new passive dispersion processes for the species and the urbanisation of the vectors. In areas of Cochabamba, Bolívia, T. cruzi infection is now considered an urban health problem and is no longer restricted to rural areas and small villages. The high infection risk in children was correlated to the high percentage of the natural infection rates of the vector and qualitative and quantitative evidence for the current active transmission of $T$. cruzi in urban areas of Cochabamba was demonstrated (Medrano-Mercado et al. 2008).

The domiciliation of vectors in the Andean Region has been discussed since 1950, when Torrico (1950) suggested that the synanthropic process of triatomines was facilitated by the habits of the inhabitants of that area, including the practice of rearing guinea pigs in their domiciles, which attracts the insect vectors to the domiciliary ecotopes. In this sense, molecular tools for detecting gene flow between wild and domiciliated populations of triatomines could aid proactive control and provide a better understanding of the colonization and reinfestation potential of this species (Abad-Franch \& Monteiro 2005, Dumonteil et al. 2007, Almeida et al. 2008).

Rhodnius prolixus Stäl, 1859 is also another example of how wild foci (Guhl et al. 2005, Pinto et al. 2005) impair the effective control of vectorial transmission and how molecular tools may help with the understanding of the eco-epidemiology of Chagas disease vectors (Fitzpatrick et al. 2008).

One of the most important achievements in the history of American trypanosomiasis was the demonstration by Dias and Pellegrino (1948) that this disease could be controlled by targeting vectors by means of spraying houses with insecticides. All control programmes targeting the interruption of vectorial transmission were developed and applied based on this finding. Today, however, the environmental pressures of deforestation, the increase of human populations and climate change require that strategies be adjusted to efficiently monitor and control the different vector species. Chagas disease vectors are obliged haematophagous insects that need at least one blood meal until repletion in each of the five nymphal instars in order to complete their life cycles. In general, these insects are eclectic in relation to food sources and are able to feed on different hosts. However, some specificity can be found among the species in natural environments. For instance, Dipetalogaster maxima (Uhler, 1894) is associated with lizards 
in deserts, Cavernicola pilosa Barber, 1937 is associated mainly with bats and the genera Rhodnius Stål, 1859 and Psamolestes Bergroth, 1911 are strictly associated with birds (Lent \& Wygodzinsky 1979). However, most of the triatomines studied feed efficiently on different hosts, including mammals, birds, reptiles and amphibians. This kind of food eclecticism is probably one of the most important characteristics allowing the triatomines to invade new habitats and to colonise artificial ecotopes (Alencar 1987, Lent \& Wygodzinsky 1979, Costa et al. 1998). The biology of the vectors studied under laboratory conditions also shows that they are able to reproduce well; for instance, they can present high fertility and egg viability, even when they are fed on animals distinct from those with which they are normally associated in their natural environment (Costa et al. 1986, Diotaiuti \& Dias 1987). This aspect of the biology of the vectors was recently explored by focusing on the manipulation of transgenic insects as a possible strategy to control the natural infection rates in endemic areas. This method utilises genetically modified symbiotic bacteria expressing anti-parasitic agents in the gut of the triatomine bug where the trypanosomes also are found. Previous studies have shown that it is possible to transform Rhodococcus rhodnii with a shuttle plasmid that contains the gene for cecropin A, an insect anti-microbial peptide (Dotson et al. 2003). Once transformed, the bacteria expressed this peptide and promoted a reduction in the number of trypanosomes or even their elimination in the digestive tube of the bug R. prolixus. Whether the paratransgenic triatomines will actually be able to interact with wild ones and spread $R$. rhodnii into the population needs further analysis (Beard et al. 2002).

During the last decade, increasing evidence suggests that the main vectors of Chagas disease present relevant sylvatic populations that pose a new control challenge, probably indicating no real chance to eliminate the vector insects from large endemic areas (Noireau et al. 2005, Sanchez-Martin et al. 2006, Feliciangeli et al. 2007, Rojas Cortez et al. 2007). This can be summed to the control challenges posed by other vectors that are already considered not eliminable due to the large rates of domiciliary infestation promoted by their sylvatic foci, such as T. brasiliensis, Panstrongylus megistus (Burmeister, 1835) and Triatoma dimidiata (Latreille, 1811). This scenario is associated with the fact that some vector species are already present in populations characterised as resistant to insecticides (Vassena et al. 2000, Piccolo et al. 2005). This process was likely the consequence of the chronic application of insecticides during the past decades. The permanent use of insecticides promoted by recurrent re-invasion processes may bring other control challenges and reveal the need to use more environmentally friendly control methods.

The Special Programme for Research and Training in Tropical Diseases has recently issued a call for proposals for the development of new control tools based on the existing knowledge of triatomine behaviour. This call was promoted by the need for new alternatives to increase the efficiency of insect control measures, especially when sylvatic populations represent an additional threat. Guerenstein and Lazzari (2009) have thoroughly reviewed the existing information about host orientation in triatomines. This ample knowledge reported by the authors indicates that the development of sampling or detection devices can be based on solid information. Other aspects of triatomine behaviour, such as aggregation and sexual signals, are being studied and may generate further alternatives for interfering with insect communication processes and manipulating their behaviour (Lorenzo et al. 2000, Manrique et al. 2006, Pontes et al. 2008).

During searches for triatomines, home owners commonly claim that no insects have been observed. However, in many cases, the houses are later shown to be infested. Traps that can monitor insects during the night when the inhabitants of the house are generally sleeping would be of great help for the control of domiciliary infestations. Also, the application of high resolution and low cost technologies, such as geometric morphometrics, is crucial to answer the relevant questions related to taxonomy and eco-epidemiologic features, assessing systematics and the analysis of domiciliated vector population dynamics (Dujardin et al. 2009).

Finally, it is important to stress that due to the dramatic impact of Chagas disease on public health and considering the level and amount of information already gathered concerning its epidemiologic aspects (Coura 2007), several recommendations were recently defined by the Andean Countries Initiative (Guhl 2007), by the Southern Cone Initiative (Dias 2007) and by the Brazilian Consensus on Chagas Disease, in 2005, aiming for the standardisation of strategies for diagnosis, treatment, prevention and control (SVS 2005).

Here, we present a list of priorities based on some of the vectorial aspects and challenges discussed in the present review: (i) the development of new strategies to explore the biological and behavioural traits of the triatomines; (ii) continuous political actions to keep the long-term monitoring activities in endemic areas, checking for the colonization and reinfestation of domiciles; (iii) more attention directed to new triatomine species that have recently emerged as a threat for the transmission of Chagas disease; (iv) implementing an effective educational programme directed at those living in communities at a high risk of Chagas transmission and, the last but not the least, (v) the improvement of the professional capacity of the technicians responsible for the execution of the vectorial control actions, a crucial step for facing the new challenges in this area (Argolo et al. 2008).

\section{ACKNOWLEDGMENTS}

To Dr. Carlos Eduardo Almeida, two anonymous referees, associated editors and Ricardo Bittencourt von Sydow, for valuable suggestions and critic review.

\section{REFERENCES}

Abad-Franch F, Monteiro F 2005. Molecular research and the control of Chagas disease vectors. An Acad Bras Ciênc 77: 437-454.

Abad-Franch F, Monteiro F 2007. A biogeography and evolution of Amazonian triatomines (Heteroptera: Reduviidae): implications for Chagas disease surveillance in humid forest ecoregions. Mem Inst Oswaldo Cruz 102 (Suppl.I): 57-70. 
Alencar JE 1987. História natural da doença de Chagas no estado do Ceará. Imprensa Universidade da UFC, Fortaleza, 341 pp.

Almeida CE, Folly-Ramos E, Peterson AT, Lima-Neiva V, Gumiel M, Duarte R, Lima MM, Locks M, Beltrão M, Costa J 2009. Could Triatoma sherlocki be vectoring Chagas disease in small mining communities in Bahia, Brazil? Med Vet Entomol, in press.

Almeida CE, Pacheco RS, Haag K, Dupas S, Dotson E, Costa J 2008. Inferring from the cyt $B$ gene the Triatoma brasiliensis Neiva, 1911 (Hemiptera: Reduviidae: Triatominae). Genetic structure and domiciliary infestation in the state of Paraíba, Brazil. Am J Trop Med Hyg 78: 791-802.

Almeida CE, Vinhaes MC, Almeida JR, Silveira AC, Costa J 2000. Monitoring the domiciliary and peridomiciliary invasion process of Triatoma rubrovaria in the state of Rio Grande do Sul, Brazil. Mem Inst Oswaldo Cruz 95: 761-768.

Argolo AM, Felix M, Pacheco R, Costa J 2008. Doença de Chagas e seus principais vetores no Brasil, $1^{\mathrm{a}}$. ed., Imperial Novo Milênio, Rio de Janeiro, vol. 1, 64 pp.

Barretto MP, Siqueira AF, Côrrea FMA 1963. Estudos sôbre reservatórios e vetores silvestres do Trypanosoma cruzi. I. Encontro do Triatoma infestans em ecótopos silvestres. Rev Inst Med Trop Sao Paulo 5: 289-293.

Beard CB, Cordon-Rosales C, Durvasula RV 2002. Bacterial symbionts of the Triatominae and their potential use in control of Chagas disease transmission. Ann Rev Entomol 47: 123-141.

Bérenger JM, Blanchet D 2007. A new species of the genus Panstrongylus from French Guiana (Heteroptera; Reduviidae; Triatominae). Mem Inst Oswaldo Cruz 102: 733-736.

Briceno-Leon R, Galvan MJ 2007. The social determinants of Chagas disease and the transformations of Latin America. Mem Inst Oswaldo Cruz 102: 109-112.

Chagas C 1909. Nova tripanozomiaze humana. Estudos sobre a morfologia e o ciclo evolutivo do Schizotrypanum cruzi n. gen. n. sp., agente etiologico de nova entidade morbida do homem. Mem Inst Oswaldo Cruz 1: 159-218.

Costa J, Almeida JR, Britto C, Duarte R, Marchon-Silva V, Pacheco R 1998. Ecotopes, natural infection and trophic resources of Triatoma brasiliensis (Hemiptera: Reduviidae: Triatominae). Mem Inst Oswaldo Cruz 93: 7-13.

Costa J, Almeida CE, Dotson EM, Lins A, Vinhaes M, Silveira AC, Beard CB 2003. The epidemiologic importance of Triatoma brasiliensis as a Chagas disease vector in Brazil: a revision of domiciliary captures during 1993-1999. Mem Inst Oswaldo Cruz 98: 443-449.

Costa J, Felix M 2007. Triatoma juazeirensis sp. nov. from the state of Bahia, Northeastern Brazil (Hemiptera:Reduviidae: Triatominae). Mem Inst Oswaldo Cruz 102: 87-90.

Costa J, Jurberg J, Almeida JR 1986. Estudos bionômicos de Dipetalogaster maximus (Uhler 1894) (Hemiptera: Reduviidae: Triatominae). I Influencia da dieta sobre o ritmo de postura, viabilidade dos ovos, curva de fertilidade e mortalidade das fêmeas. Mem Inst Oswaldo Cruz 81: 365-380.

Costa J, Peterson AT, Beard CB 2002. Ecological Niche Modeling and differentiation of populations of Triatoma brasiliensis Neiva, 1911, the most important Chagas disease vector in Northeastern Brazil (Hemiptera: Reduviidae: Triatominae). Am J Trop Med Hyg 67: 516-567.

Costa J, Peterson AT, Dujardin JP 2009. Morphological evidence suggests homoploid hybridization as a possible mode of speciation in the Triatominae (Hemiptera: Heteroptera: Reduviidae). Infect Genet Evol 9: 263-270.
Costa JM, Argolo AM, Felix M 2006. Redescription of Triatoma melanica Neiva \& Lent, 1941, new status (Hemiptera: Reduviidae: Triatominae). Zootaxa 1385: 47-52.

Coura JR 2007. Chagas disease: what is known and what is needed - A background article. Mem Inst Oswaldo Cruz 102 (Suppl. I): $113-122$

Coura JR, Barrett TV, Naranjo MA 1994. Ataque de populações humanas por triatomíneos silvestres no Amazonas: uma nova forma de transmissão chagásica? Rev Soc Bras Med Trop 27: 251-253.

Coura JR, Junqueria A, Fernandes O, Valente A, Miles MA 2002. Emerging Chagas disease in the Amazonian Brazil. Trends Parasitol 18: 171-176.

Dias JCP 2007. Southern Cone Initiative for the elimination of domestic populations of Triatoma infestans and the interruption of transfusional Chagas disease. Historical aspects, present situation and perspectives. Mem Inst Oswaldo Cruz 102 (Suppl. I): 11-18.

Dias E, Pellegrino J 1948. Alguns ensaios com o gammexane no combate aos transmissores da doença de chagas. Bras Med 62: $185-191$

Diotaiuti L, Dias JCP 1987 Estudo do ciclo evolutivo de Rhodnius neglectus alimentados em pombos ou camundongos. Rev Soc Bras Med Trop 20: 95-100.

Diotaiuti L, Paula OR, Falcão PL, Dias JCP 1995. Avaliação do programa do controle vetorial da doença de Chagas em Minas Gerais, Brasil, com referência especial ao Triatoma sordida. Bol Of Sanit Panan 118: 211-219.

Dotson EM, Plikaytis B, Shinnick TM, Durvasula RV, Beard CB 2003. Transformation of Rhodococcus rhodnii, a symbiont of the Chagas disease vector Rhodnius prolixus, with integrative elements of the L1 mycobacteriophage. Infect Genet Evol 3: 103-109.

Dujardin JP, Costa J, Bustamante D, Jaramillo N, Catala S 2009. Deciphering morphology in Triatominae: the evolutionary signals. Acta Trop 110: 101-111.

Dumonteil E, Tripet F, Ramirez-Sierra MJ, Payet V, Lanzaro G, Menu F 2007. Assessment of Triatoma dimidiata dispersal in the Yucatan Peninsula of Mexico by morphometry and micro-satellite markers. Am J Trop Med Hyg 76: 930-937.

Fé NF, França MS, Carvalho-Costa FA 2009. Reassessing the entomological investigation around the first autochthonous case of Chagas disease in western Brazilian Amazon. Mem Inst Oswaldo Cruz 104 (Suppl. I): 121-123.

Feliciangeli MD, Sanchez-Martin M, Marrero R, Davies C, Dujardin JP 2007. Morphometric evidence for a possible role of Rhodnius prolixus from palm trees in house re-infestation in the state of Barinas (Venezuela). Acta Trop 101: 169-177.

Fitzpatrick S, Feliciangeli MD, Sanchez-Martin MJ, Monteiro FA, Miles MA 2008. Molecular genetics reveal that silvatic Rhodnius prolixus do colonize rural houses. Plos Negl Trop Dis 2: e210

Forattini OP, Ferreira OA, Silva EOS, Rabello EX 1978. Aspectos ecológicos da tripanosomíase Americana. XII - Variação regional da tendência de Panstrongylus megistus à domiciliação. Rev Saude Publica 12: 209-233.

Forero D, Weirauch C, Baena M 2004. Synonymy of the reduviid (Hemiptera: Heteroptera) genus Torrealbaia (Triatominae) with Amphibolus (Harpactorinae), with notes on Amphibolus venator (Klug, 1830). Zootaxa 670: 1-12.

Freitas SPC, Freitas ALC, Gonçalves TCM 2004. Occurrence of Panstrongylus lutzi, in peridomiciliary areas, state of Ceará, Brazil. Rev Saude Publica 38: 578-580. 
Galvão C, Angulo VM 2006. Belminus corredori, a new species of Bolboderini (Hemiptera: Reduviidae: Triatominae) from Santander, Colombia. Zootaxa 1241: 61-68.

Galvão C, Carcavallo R, Rocha DS, Jurberg J 2003. A checklist of the current valid species of the subfamily Triatominae Jeannel, 1919 (Hemiptera: Reduviidae) and their geografical distribution with nomenclatural and taxonomic notes. Zootaxa 202: 1-36.

Galvão C, Jurberg J, Carcavallo RU, Segura CA, Girón IG, Curto de Casas SI 1998. Distribuição geográfica e dispersão alti-latitudinal de alguns gêneros e espécies da tribo Triatomini Jeannel, 1919 (Hemíptera: Reduviidae: Triatominae). Mem Inst Oswaldo Cruz 93: 33-38.

Garcia MHHM, Souza L, Souza RCM, Paula AS, Borges EC, Barbosa SE, Schofield CJ, Diotaiuti L 2005. Occurrence and variability of Panstrongylus lutzi in the state of Ceará, Brazil. Rev Soc Bras Med Trop 38: 410-415.

Gonçalves TCM, Oliveira E, Dias LS, Almeida MD, Nogueira WO, Pires FDA 1998. An investigation on the ecology of Triatoma vitticeps (Stål, 1859) and its possible role in the transmission of Trypanosoma cruzi in the locality of Triunfo, Santa Maria Madalena municipal district, state of Rio de Janeiro, Brazil. Mem Inst Oswaldo Cruz 93: 711-717.

Guarneri AA, Lazzari CR, Diotaiuti L, Lorenzo MG 2002. The effect of relative humidity on the behaviour and development of Triatoma brasiliensis. Physiol Entomol 27: 142-147.

Guarneri AA, Lazzari CR, Xavier AAP, Diotaiuti L, Lorenzo MG 2003. The effect of temperature on the behaviour and development of Triatoma brasiliensis. Physiol Entomol 28: 185-191.

Guerenstein PG, Lazzari CR 2009. Host-seeking: how triatomines acquire and make use of information to find blood. Acta Trop 110: $148-158$.

Guhl F 2007. Chagas disease in Andean countries. Mem Inst Oswaldo Cruz 102 (Suppl.I): 29-38.

Guhl F, Pinto N, Marín D, Herrera C, Aguilera G, Naranjo JM, Vallejo G 2005. Primer reporte de Rhodnius prolixus Stål, en Elaeis guineensis variedad Papúa, en plantaciones agroindustriales de Villanueva, Casanare. Biomedica 25 (Suppl. I): 158-159.

Gurevitz JM, Ceballos LA, Kitron U, Gürtler RE 2006. Flight initiation of Triatoma infestans (Hemiptera: Reduviidae) under natural climatic conditions. J Med Entomol 43: 143-150.

IBAMA - Instituto Brasileiro do Meio Ambiente e dos Recursos Naturais Renováveis 2009. Available from: http://www.ibama. gov.br/ecossistemas/home.htm. [Accessed on April 12 2009].

IBGE - Instituto Brasileiro de Geografia e Estatística 2008. Available from: http://www.ibge.gov.br/. [Accessed April 12 2009].

Lent H, Wygodzinsky P 1979. Revision of the Triatominae (Hemiptera: Reduviidae) and their significance as vector of Chagas' disease. Bull Amer Mus Nat History 163: 123-520.

Lopez-Cardenas J, González-Bravo FE, Salazar-Schettino PM, Gallaga-Solorzano JC, Ramírez-Barba E, Martínez-Mendez J, Sanchez-Cordero V, Peterson AT, Ramsey J 2005. Fine-scale predictions of distributions of Chagas disease vectors in the state of Guanajuato, Mexico. J Med Entomol 42: 1068-1081.

Lorenzo MG, Lorenzo Figueiras AN, Manrique G, Pires HHR, Vitta ACR, Diotaiuti L, Lazzari CR, Zani CL 2000. Chemical signals involved in the communication of triatomine bugs. Mem Inst Oswaldo Cruz 95 (Suppl. II): 60-61.

Manrique G, Vitta ACR, Ferreira RA, Zani CL, Unelius CR, Lazzari CR, Diotaiuti L, Lorenzo MG 2006. Chemical communication in Chagas disease vectors. Source, identity and potential function of volatiles released by the metasternal and Brindley's glands of Triatoma infestans adults. J Chem Ecol 32: 2035-2052.

Martinez E, Chávez T, Sossa D, Aranda R, Vargas B, Vidaurre P 2007. Triatoma boliviana $\mathrm{sp}$. $\mathrm{n}$. de los valles subandinos de La Paz, Bolivia (Hemiptera: Reduviidae: Triatominae), similar a Triatoma nigromaculata Stål, 1859. Bol Inst Invest Salud Desar 3: 1-11.

Matta A 1919. Um novo reduvídeo do Amazonas, Rhodnius brethesi n. sp. Amazonas Med 2: 93-94.

Mazza S 1943. Comprobaciones de Triatoma platensis, Eutriatoma oswaldoi, Panstrongylus seai y Psammolestes coreodes en la Provincia de Santiago del Estero, todos ellos sin infestación y de Eutriatoma sordida con infestación por $S$. cruzi. Otros datos sobre infestación esquizotripanósica natural silvestre de Triatoma infestans. Prensa Med Arg 30: 1-23.

Medrano-Mercado N, Ugarte-Fernandez R, Butrón V, Uber-Busek S, Guerra HL, Araújo-Jorge TC, Correa-Oliveira R 2008. Urban transmission of Chagas disease in Cochabamba, Bolivia. Mem Inst Oswaldo Cruz 103: 423-430.

Neiva A 1910. Informações sobre a biologia de Conorrhinus megistus. Mem Inst Oswaldo Cruz 2: 206-212.

Neiva A, Lent H 1941. Sinopse dos Triatomíneos. Rev Entomol 12: 62-92.

Neiva-Lima V, Gumiel MX, Oliveira AGMZ, Dotson E, Lima MM, Cabello P, Dujardin JP, Almeida CE, Costa J 2008. High phenotypic variability was detected in a hybrid zone of the Triatoma brasiliensis species complex in the state of Pernambuco, Brazil (Hemíptera: Heteroptera: Reduviidae). Reunião de Pesquisa Básica em Doença de Chagas. Rev Inst Med Trop São Paulo 45: 203-204.

Noireau F, Abad-Franch F, Valente SAS, Dias-Lima A, Lopes CM, Cunha V, Valente VC, Palomeque FS, Carvalho-Pinto CJ, Sherlock I, Aguilar M, Steindel M, Grisard EC, Jurberg J 2002. Trapping Triatominae in silvatic habitats. Mem Inst Oswaldo Cruz 97: 61-63.

Noireau F, Cortez MR, Monteiro FA, Jansen AM, Torrico F 2005. Can wild Triatoma infestans foci in Bolívia jeopardize Chagas disease control efforts? Trends Parasitol 21: 7-10.

Noireau F, Flores R, Gutierrez T, Abad-Franch F, Flores E, Vargas F 2000. Natural ecotopes of Triatoma infestans dark morph and other wild triatomines in the Bolivian Chaco. Trans $R$ Soc Trop Med Hyg 94: 23-27.

Panzera F, Dujardin JP, Nicolini P, Caraccio MN, Rose V, Tellez T, Bermudez H, Bargues MD, Mas-Coma S, O'Connor JE, Perez R 2004. Genomic changes of Chagas disease vector, South America. Emerg Inf Dis 10: 438-446.

Patterson JS, Barbosa SE, Feliciangeli MD 2009. On the genus Panstrongylus Berg 1879: Evolution, ecology and epidemiological significance. Acta Trop 110: 187-199.

Pelli A, Silva MA, Sarmento FR, Martins E, Mata SA, Domingues MA, Ramirez LE 2007. Population parameters for Triatoma sordida Stål, 1859: the most frequent vector for Chagas disease in the Triangulo Mineiro (Heteroptera: Triatominae). Rev Soc Bras Med Trop 40: 25-28.

Picollo MI, Vassena CV, Santo Orihuela P, Barrios S, Zaidemberg M and Zerba EN 2005. High resistance to pyrethroid insecticides associated with ineffective field treatments in Triatoma infestans (Hemiptera: Reduviidae) from Northern Argentina. J Med Entomol 42: 637-642.

Pinto N, Marín D, Herrera C, Vallejo G, Naranjo JM, Guhl F 2005. Comprobación del ciclo selvático de Rhodnius prolixus Stål en reductos de Attalea butyracea en el departamento de Casanare. Biomedica 25 (Suppl. 1): 159. 
Pontes GB, Bohman B, Unelius CR, Lorenzo MG 2008. Metasternal gland volatiles and sexual communication in the triatomine bug, Rhodnius prolixus. J Chem Ecol 34: 1573-1561.

Rojas Cortez M, Emperaire L, Piccinali RV, Gurtler RE, Torrico F, Jansen AM, Noireau F 2007. Sylvatic Triatoma infestans (Reduviidae: Triatominae) in the Andean valleys of Bolivia. Acta Trop 102: 47-54.

Romaña CA, Brunstein D, Collin-Delavaud A, Sousa O, Ortega-Barría E 2003. Public policies of development in Latin America and Chagas' disease. Lancet 362: 579.

Sarquis O, Borges-Pereira J, Maccord JR, Ferreira GT, Cabello PH, Lima MM 2004. Epidemiology of chagas disease in Jaguaruana, Ceará, Brazil. I. Presence of triatomines and index of Trypanosoma cruzi infection in four localities of a rural area. Mem Inst Oswaldo Cruz 99: 263-270.

Sanchez-Martin MJ, Feliciangeli MD, Campbell-Lendrum D, Davies C 2006. Could the Chagas disease elimination programme in Venezuela be compromised by reinvasion of houses by sylvatic Rhodnius prolixus bug populations? Trop Med Int Health 11: 1585-1593.

Sandoval CM, Pabón E, Jurberg J, Galvão C 2007. Belminus ferroae n. sp. from the Colombian North-East, with a key to the species of the genus (Hemiptera: Reduviidae: Triatominae). Zootaxa 1443: 55-64.
Schofield CJ, Galvão C 2009. Classification, evolution and species groups within the Triatominae. Acta Trop 110: 88-100.

Silveira AC 2000. Situação do controle da transmissão vetorial da doença de Chagas nas Américas. Cad Saude Publica 16: 35-42.

Silveira AC, Vinhaes MC 1999. Elimination of vector-borne transmission of Chagas disease. Mem Inst Oswaldo Cruz 94 (Suppl. I): 405-411.

Souza RCM, Barbosa SE, Sonoda IV, Azeredo BMV, Romanha AJ, Diotaiuti L 2008. Population dynamics of Triatoma vitticeps (Stal, 1859) in Itanhomi, Minas Gerais, Brazil. Mem Inst Oswaldo Cruz 103: 14-20.

SVS - Secretaria de Vigilância em Saúde do Ministério da Saúde 2005. Available from: ftp://ftp.cve.saude.sp.gov.br/doc_tec/ZOO/ chagas05_consenso_svs.pdf. [Accessed on June 11 2009].

Torrico RA 1946. Hallazgo de Eratyrus mucronatus, infestación natural de "vinchucas" de cerro y Eutriatoma sordida en Cochabamba. An Lab Central Cochabamba 1: 19-23.

Torrico RA 1950. Conocimientos actuales sobre la enfermedad de Chagas en Bolivia. Bol Of Sanit Panam 29: 827-41.

Vassena CV, Picollo MI, Zerba EM 2000. Insecticide resistance in Brazilian Triatoma infestans and Venezuelan Rhodnius prolixus. Med Vet Entomol 14: 51-55. 